\title{
Constitutional Adjudication and Constitutional Politics in the United Kingdom: The Miller II Case in Legal and Political Context
}

\author{
Mark Elliott*
}

\section{INTRODUCTION}

For a number of years there has been nothing at all unusual about the United Kingdom finding itself in a state of constitutional upheaval; indeed, for some time, this has been the UK constitution's default setting. This has sometimes been as a result of long-anticipated and carefully planned reforms, such as the enactment, in the late 1990s, of legislation to give domestic effect to the European Convention on Human Rights ${ }^{1}$ and to introduce devolved systems of government in Scotland, Wales and Northern Ireland. ${ }^{2}$ In contrast, more recent upheaval is attributable to often unexpected reactions to often unexpected events. For example, legislation making substantial changes to the devolution scheme in Scotland ${ }^{3}$ - providing, among other things, for the constitutional permanence of the Scottish Parliament and Government ${ }^{4}$ - was enacted to implement panicked promises made by UK politicians in the dying days of the Scottish independence referendum campaign, at which point a vote in favour of independence seemed a distinct possibility. And then, needless to say, there is Brexit - about which it is

\footnotetext{
*Professor of Public Law, University of Cambridge; Fellow, St. Catharine's College, Cambridge.

${ }^{1}$ Human Rights Act 1998.

${ }^{2}$ Scotland Act 1998; Government of Wales Act 1998; Northern Ireland Act 1998.

${ }^{3}$ Scotland Act 2016.

${ }^{4}$ Scotland Act 2016, s 1 (inserting a new s 63A into the Scotland Act 1998).
}

European Constitutional Law Review, 16: 625-646, 2020

(C) The Author(s), 2021. Published by Cambridge University Press on behalf of European Constitutional Law Review. This is an Open Access article, distributed under the terms of the Creative Commons Attribution licence (http://creativecommons.org/licenses/by/4.0/), which permits unrestricted re-use, distribution, and reproduction in any medium, provided the original work is properly cited. doi:10.1017/S1574019620000401 
almost impossible to be guilty of hyperbole when describing its constitutional implications, so numerous and potentially far-reaching are they.

This article makes no attempt to catalogue those implications. But it does take as its focus a landmark judgment rendered against a dramatic, Brexit-related backdrop. In the late summer of 2019, the UK Government sought to suspend Parliament, precipitating a Supreme Court judgment holding the attempt to be unlawful, clearing the way for the immediate reopening of the legislature. These legally and constitutionally explosive developments took place in a politically febrile atmosphere, with the UK apparently hurtling towards the cliff-edge of leaving the EU without any withdrawal agreement, the Government seeking to suspend Parliament, and Parliament, in its turn, racing - successfully, as it happens $s^{5}$ - to enact legislation requiring Ministers to seek an extension to the EU exit process. $^{6}$

It was in these unprecedented circumstances that the Supreme Court issued its incendiary judgment in the Miller II case. ${ }^{7}$ In this article, I examine that judgment and contend that, contrary to arguments advanced by the Government in the course of the litigation and contrary to criticism that the judgment has attracted, the Supreme Court arrived at the correct conclusion and did so on the basis of legal and constitutional reasoning that was eminently sound. In advancing this argument, I contend that the Supreme Court's judgment was at once both orthodox and path-breaking. I also contend that, to the extent that it may have been legally and constitutionally innovative, such innovation was anchored in a secure foundation of fundamental principle. ${ }^{8}$ I then conclude by stepping back from the detail of the judgment to consider its broader implications. Before doing any of

${ }^{5}$ European Union (Withdrawal) (No 2) Act 2019.

${ }^{6}$ Under the Art. 50 of the Treaty on European Union.

${ }^{7} R$ (Miller) v Prime Minister [2019] UKSC 41, [2020] AC 373 ('Miller II). All references to Miller II in this article are to the Supreme Court's judgment in that case unless otherwise indicated. The Miller II case - unsurprisingly in the light of its significance - has already generated a substantial literature. Contributions to the debate regarding the case include P. Craig, 'The Supreme Court, Prorogation and Constitutional Principle', Public Law (2020) p. 248; D. Knight, 'Brexit, Prorogation and Popcorn: Implications of Miller (No 2) for New Zealand', 51 Victoria University of Wellington Law Review (2020) p. 249; A. McHarg, 'The Supreme Court's Prorogation Judgment: Guardian of the Constitution or Architect of the Constitution?', 24 Edinburgh Law Review (2020) p. 88. A number of particularly critical commentaries, published under the auspices of the Judicial Power Project, are referred to later in this article.

${ }^{8}$ This part of my argument draws upon an analysis that I published online shortly after the judgment in Miller II was given. See M. Elliott, 'A New Approach to Constitutional Adjudication? Miller II in the Supreme Court', Public Law for Everyone, 24 September 2019, available at publiclawforeveryone.com/2019/09/24/the-supreme-courts-judgment-in-cherry-miller-no-2-a-newapproach-to-constitutional-adjudication/ $\rangle$, visited 15 December 2020. 
those things, however, I begin with a sketch of the issues that were at stake, and of the judgment that the Supreme Court delivered, in the Miller II case.

\section{THE CASE}

At the heart of Miller II was the notion of prorogation. The constitutional effects of prorogation were summarised by Lady Hale and Lord Reed, the then President and Deputy President of the Supreme Court, in the joint judgment that they gave on behalf of a unanimous 11-member bench:

'Parliamentary sittings are normally divided into sessions, usually lasting for about a year, but sometimes less and sometimes, as with the current session, much longer. Prorogation of Parliament brings the current session to an end. The next session begins, usually a short time later, with the Queen's Speech [in which the Government's new legislative programme is set out]. While Parliament is prorogued, neither House can meet, debate and pass legislation. Neither House can debate Government policy. Nor may members of either House ask written or oral questions of Ministers. They may not meet and take evidence in committees. In general, Bills which have not yet completed all their stages are lost and will have to start again from scratch in the next session of Parliament.'

The power to prorogue, or suspend, Parliament is a prerogative power exercised by the Queen on the advice of the Prime Minister. As a prerogative power, the power to prorogue Parliament arises not under legislation but at common law, and is recognised by - and, as we will see, its exercise can be reviewed by - the courts. It is also important to note that the power is recognised by Parliament itself and is acknowledged by its own rules and procedures. ${ }^{10}$ The key legal issue in Miller II was whether it had been unlawful for Parliament to be prorogued, and for the Prime Minister to have advised the Queen to prorogue Parliament, for a period of five weeks in September and October 2019. When a lower English court, the Divisional Court, ${ }^{11}$ addressed this matter, it concluded that the question was nonjusticiable, meaning that it would be constitutionally improper and impermissible for the Court to rule on the lawfulness of prorogation. ${ }^{12}$ In contrast, in parallel litigation in Scotland on the same matter, the Inner House of the Court of Session considered itself to be under no such justiciability-related inhibition, concluding

${ }^{9}$ Miller II, supra n. 7, at [2]. See also Erskine May's treatise on the law, privileges, proceedings and usage of Parliament (25th edition, 2019) para 8.6 ('Erskine May').

${ }^{10}$ See, e.g., Erskine May, supra n. 9, ch. 8.

${ }^{11}$ A Divisional Court is a court consisting of at least two (and, in this instance, three) judges of the High Court of England and Wales.

${ }^{12} R$ (Miller) v Prime Minister [2019] EWHC 2381 (QB), [2019] ACD 136. 
that the advice and the prorogation were unlawful on the ground that they had been used improperly so as to 'stymie' Parliament from discharging its constitutional functions. ${ }^{13}$

The Supreme Court disagreed with the Divisional Court, holding that the issues raised by the case were properly justiciable. Like the Inner House of the Court of Session, the Supreme Court concluded that the advice and the prorogation were unlawful. However, the Supreme Court reached this conclusion for different reasons. Although it was widely believed that the motive behind and the purpose of prorogation was, as the Scottish court had put it, to 'stymie' Parliament - in particular by attempting to prevent it from enacting legislation requiring the UK Government to seek an extension to the Article 50 process - the Supreme Court did not invoke such considerations. Rather than addressing questions of motive or purpose it focused on the effect of prorogation, holding that the power to prorogue does not extend to a situation where a fundamental constitutional principle would be impinged upon without a reasonable justification. As the Court put it in a key passage of its judgment:

'[A] decision to prorogue Parliament (or to advise the monarch to prorogue Parliament) will be unlawful if the prorogation has the effect of frustrating or preventing, without reasonable justification, the ability of Parliament to carry out its constitutional functions as a legislature and as the body responsible for the supervision of the executive. In such a situation, the court will intervene if the effect is sufficiently serious to justify such an exceptional course..$^{14}$

The Court concluded that no such justification had been offered, given that prorogation for such a long period was not necessary to facilitate the Government's professed objective of securing a Queen's speech and a new legislative session. Having reached this conclusion, the Court further held that since there was no, and never had been any, valid legal basis for the prorogation, it was void $a b$ initio and should be regarded as never having had any legal effect. Parliament therefore resumed normal business the following day.

The Supreme Court's judgment in Miller II provoked a variety of reactions in both political and legal quarters. For some, it amounted to a welcome and wholly appropriate reassertion of fundamental constitutional principle. For others, it represented an egregious example of judicial overreach. Particularly trenchant criticism has been levelled at the judgment in papers published by the

\footnotetext{
${ }^{13}$ Cherry v Advocate General for Scotland [2019] CSIH 49. In Miller II, the Supreme Court heard appeals against the decisions of both the Divisional Court in the Miller litigation and the Inner House of the Court of Session in Cherry.

${ }^{14}$ Miller II, supra n. 7, at [2].
} 
Judicial Power Project. ${ }^{15}$ In considering whether such criticism is warranted, it is helpful to focus on certain key aspects of the case that might be thought to signify the breaking of significant new ground and which might therefore be - and in some instances have been - characterised as judicial overreach. In fact, I will show that in none of these respects does the reasoning in Miller II signify a radical change in thinking, and will argue that while the judgment is certainly ground-breaking in certain respects, any innovations contained within the reasoning are ones that are wholly warranted by reference to established principle. In the following sections of this article, I examine three critical aspects of the judgment and the reasoning underpinning them, according to which: (i) fundamental constitutional principles were implicated by the Government's attempt to prorogue Parliament; (ii) the application of those principles raised a justiciable question for the Court; and (iii) those principles operated to limit the scope of the prorogation power, the extent of which fell to be determined by means of a more than merely minimal level of judicial scrutiny.

\section{FUNDAMENTAL CONSTITUTIONAL PRINCIPLES}

The first respect, then, in which the judgment might be thought to break new ground concerns the two constitutional principles that the Court identified and relied upon. The use to which those principles was put within the factual matrix of the case is the subject of a later section of this article; my concern for the time being relates to the content of those principles. The principles in question are the sovereignty of Parliament and what the Court described as 'parliamentary accountability' but which is more commonly referred to as executive accountability (that is, the accountability of the executive to Parliament). The Court might be thought to have committed the sin of overreach in respect of each of these two principles in different ways. As regards parliamentary sovereignty, the concern may be that the Court unwarrantedly extended the principle. ${ }^{16}$ In respect of executive accountability, the concern may be that no such legal principle exists

\footnotetext{
${ }^{15}$ M. Loughlin, The Case of Prorogation (Policy Exchange, 2019), available at (judicialpowerproject. org.uk/the-case-of-prorogation>; J. Finnis, 'The Unconstitutionality of the Supreme Court's Prorogation Judgment' (London, Policy Exchange 2019), available at (judicialpowerproject. org.uk/the-unconstitutionality-of-the-supreme-courts-prorogation-judgment-john-finnis $\rangle$; J. Finnis, 'The Law of the Constitution before the Court' (London, Policy Exchange 2020), available at 〈judicialpowerproject.org.uk/the-law-of-the-constitution-before-the-court〉, all visited 15 December 2020. Aileen McHarg, supra n. 7, is also strongly critical of the judgment.

${ }^{16}$ For instance, Loughlin, supra n. 15, at p. 16, contends that 'in order to justify extending its supervision of the limits of [the prorogation] power by reference to the sovereignty principle' the court attempted to 'transform a formal principle into a functional principle'. Loughlin goes on to argue that this approach is both 'heterodox' and 'misconceived'.
} 
and that the Court thus fell into error by investing a mere (political) constitutional convention with legal force. ${ }^{17}$ Each of these concerns, however, is misplaced. It will be helpful to consider them in turn, beginning with parliamentary sovereignty.

That parliamentary sovereignty is a fundamental principle of the UK constitution is entirely uncontentious. What is more novel is the inference that the Court was prepared to draw from that principle. The Court stated, in entirely orthodox terms, that the principle means that 'laws enacted by the Crown in Parliament are the supreme form of law in our legal system, with which everyone, including the Government, must comply'. ${ }^{18}$ However, while this may be considered the kernel of the principle, the Court went on to say that the principle is not thus confined. Rather, the core principle produces penumbral implications that can themselves properly be thought of as part of the principle itself - and which thus, as aspects of the sovereignty principle, occupy an axiomatic constitutional position.

This is hardly controversial. Indeed, there are many existing examples of precisely this phenomenon. One such example, as the Court pointed out, is that prerogative power may not be used in ways that are incompatible with legislation enacted by Parliament - a principle that was established in the $17^{\text {th }}$ century in the Case of Proclamations. ${ }^{19}$ This underpins the so-called De Keyser principle,${ }^{20}$ according to which the prerogative may not be relied upon when the relevant matter is governed by statute, as well as a broader principle set out in the Fire Brigades Union case ${ }^{21}$ according to which the exercise of prerogative power may not lawfully be used so as to frustrate a statutory regime. Such matters were in play before the Supreme Court in the Miller I case, ${ }^{22}$ in which it was held that the EU exit process under Article 50 of the Treaty on European Union could not be initiated under prerogative power because to do so would conflict with statute law. ${ }^{23}$ A second implication of parliamentary sovereignty, which is properly understood to be part and parcel of the principle itself, is the long-established proposition that

\footnotetext{
${ }^{17}$ This position is adopted by, among others, Richard Ekins in written evidence submitted to the House of Commons Public Administration and Constitutional Affairs Committee, 〈data. parliament.uk/writtenevidence/committeeevidence.svc/evidencedocument/public-administrationand-constitutional-affairs-committee/prorogation-and-the-implications-of-the-supreme-courtjudgment/written/106116.html), visited 15 December 2020.

${ }^{18}$ Miller II, supra n. 7, at [41].

${ }^{19}(1611) 12$ Co Rep 74.

${ }^{20}$ Attorney General v De Keyser's Royal Hotel Ltd [1920] AC 508.

${ }^{21} R \mathrm{v}$ Secretary of State for the Home Department, ex p Fire Brigades Union [1995] 2 AC 513.

${ }^{22} R$ (Miller) v Secretary of State for Exiting the European Union [2017] UKSC 5, [2018] AC 61.

${ }^{23}$ On the Miller I case generally, see M. Elliott et al. (eds.), The UK Constitution After Miller: Brexit and Beyond (Hart Publishing 2018).
} 
Parliament cannot bind its successors, ${ }^{24}$ meaning on this view that - paradoxically - the sovereign legislature in incapable of enacting legislation that would constrain its own powers. A third implication is one that the Supreme Court recently drew in Privacy International, ${ }^{25}$ in which several of the Justices attached weight to the view, expressed by Laws LJ in Cart, ${ }^{26}$ that access to court is a logical corollary of the principle of parliamentary sovereignty, authoritative judicial interpretation and curation of legislation being a prerequisite if Parliament is to have the capacity to enact effective law. On this view, judicial resistance to ouster clauses - that is, provisions in legislation that exclude, or appear to exclude, judicial review of executive action - in service of the rule of law involves not curtailing but fulfilling the requirements of parliamentary sovereignty.

Miller II involves the drawing of a further inference from parliamentary sovereignty. The Court held that sovereignty 'would ... be undermined as the foundational principle of our constitution if the executive could, through the use of the prerogative, prevent Parliament from exercising its legislative authority for as long as it pleased'. ${ }^{27}$ This does not imply that it is for the Court to determine what constitutes an acceptable period of prorogation. Rather, it means that it would be incompatible with parliamentary sovereignty for the executive to have legally unfettered authority to prorogue Parliament. A response to this argument might be that parliamentary sovereignty requires only that the legislation that Parliament happens to pass should be respected by others, but that the sovereignty principle has no bearing on whether in the first place Parliament has the opportunity to enact legislation. But such an argument would be sustainable only if the sovereignty principle were to be understood as a merely arid, technical rule about the hierarchical legal status of legislation enacted by Parliament. An alternative, and arguably better, view is that it is a fundamental principle that determines and reflects the nature of constitutional democracy in the UK. Looked at in this way, the additional penumbral implication ascribed by the Court in Miller II to parliamentary sovereignty is wholly defensible, albeit that it is admittedly a step beyond the implications that court had previously attached to the doctrine.

This point can perhaps be made most effectively by considering what would have followed if the Court had decided Miller II in such a way as to ascribe to the executive branch an untrammelled power to prorogue Parliament. The upshot of such a decision would have been to accord to the executive a legally uncontrollable power that would have equipped it to render the sovereignty of Parliament a dead letter by proroguing Parliament at will, potentially for long periods and

\footnotetext{
${ }^{24}$ Ellen Street Estates Ltd v Minister of Health [1934] 1 KB 590.

${ }^{25} R$ (Privacy International) v Investigatory Powers Tribunal [2019] UKSC 22, [2020] AC 491.

${ }^{26} R$ (Cart) v Upper Tribunal [2010] EWCA Civ 859, [2011] QB 120.

${ }^{27}$ Miller II, supra n. 7, at [42].
} 
repeatedly. This, in turn, would have failed to pay any attention to the democratic considerations that, in the first place, ought to form a critical component of any contemporary account of the normative basis of the doctrine of parliamentary sovereignty. Ultimately, that doctrine involves the ascription of astonishingly broad - indeed, legally unlimited - powers to the legislative branch, the modern justifiability of which necessarily turns upon that branch's democratic credentials. To cling to the notion of a sovereign Parliament with wholly unalloyed lawmaking competence that was vulnerable to legally uncontrollable powers of executive neutralisation would be absurd, since it would preserve those aspects of the sovereignty principle that go to the legal status of parliamentary sovereignty whilst dismantling the democratic scaffolding that supplies the normative support for the existence of such expansive powers in the first place. The Supreme Court's position in respect of parliamentary sovereignty in Miller II may thus break new ground, in the sense that it involves a fresh articulation of the implications of the doctrine, but it is new ground that is underpinned by a firm foundation of constitutional principle.

Alongside parliamentary sovereignty, the Court in Miller II placed considerable weight on the notion of executive accountability. This, said the Court, invoking the judgment of Lord Carnwath in Miller $I^{28}$ is no less fundamental to the constitution than parliamentary sovereignty. In one sense, this certainly breaks no new ground: the political convention of ministerial accountability to Parliament is a long-established one, albeit that it is sometimes - and, it might be thought, increasingly - honoured in the breach. ${ }^{29}$ However, the question arises whether the Court took the step of giving legal force to a political convention. Such a step would certainly break new ground and would, at least on a traditional view, be improper, since it would contradict the clear position that the Supreme Court affirmed in Miller $I$, in which it was said that courts are 'neither the parents nor the guardians of political conventions' and are instead 'merely observers' of them, meaning that courts 'cannot give legal rulings' on, let alone enforce, such conventions. ${ }^{30}$

In fact, the Court in Miller II did not transgress this self-denying ordinance because it did not in the first place enforce a political convention. Instead, the Court took cognisance of the underlying constitutional reason or principle that underpins and animates the convention of accountability to Parliament. The principle in question is that in a parliamentary democracy, there must be adequate opportunity for the executive government to account to and to be held to account by the legislature. There is no reason why this constitutional principle cannot both

\footnotetext{
${ }^{28}$ Miller I, supra n. 22.

${ }^{29}$ For discussion, see L. Andrews, 'Brexit, Cabinet Norms and the Ministerial Code: Are we Living in a Post-Nolan Era?', 91 Political Quarterly (2020) p. 125 at p. 128-129.

${ }^{30}$ Miller I, supra n. 22, at [146].
} 
underpin a constitutional convention - and thus institutionalise a required mode of political behaviour - while also serving, where relevant, as a constitutional standard to be applied when assessing the lawfulness of executive action. (Nor is there any reason why the constitutional arrangements for executive accountability should not inform judicial reasoning in other relevant respects. Indeed, as Paul Craig has noted, such arrangements have long, and uncontroversially, informed judicial deliberations upon questions regarding the standard of judicial review and judicial deference to executive judgement. ${ }^{31}$ )

It is a failure to recognise that constitutional principle can, in this way, sound in both the political and legal spheres that has led some critics of Miller II into error. For instance, Richard Ekins acknowledges that the principle of accountability 'underpins a range of conventions and practices which make up our political constitution, in which the Government is formed by and accountable to the Houses of Parliament, especially the Commons' but goes on to argue that while the principle is sometimes noted by courts, it is 'not a legal principle and cannot justify novel judicial intervention. ${ }^{32}$ This, however, is misconceived. The fact that a given principle is recognised in and shapes the political-constitutional realm does not and should not preclude it from also producing effects in the legal-constitutional realm. Indeed, it would be perverse if the institutionalisation of a given principle in the form of a political convention served to preclude that principle from reverberating to any extent in legal terms. There is no reason why a suitably important and relevant constitutional principle should not - and there is every reason why it should - be capable of sounding in both the political and legal spheres.

This is not, however, to argue in favour of judicial enforcement of constitutional convention - and, indeed, the Supreme Court in Miller II did not enforce a convention. Rather, this constitutional worldview, like the Miller II judgment itself, reflects the reality that the dividing line between the political and legal spheres of the constitution is not rigid, and that fundamental principle can and does inform both political practices and legal analysis. Viewed in this way, the legal significance ascribed by the Court to the constitutional principle underpinning the convention of accountability to Parliament is perfectly orthodox and serves as an important reminder that the legal and the political constitutions are related as well as distinct.

\section{JUSTICIABILITY}

As noted above, when Miller II was before the Divisional Court, it concluded that the relevant question was non-justiciable such that it was simply not fit for judicial

\footnotetext{
${ }^{31}$ Craig, supra n. 7 , at 258-259.

${ }^{32}$ Ekins, supra n. 17 , at [15].
} 
consideration. In disagreeing with the lower court on this key point, the Supreme Court defined that question very carefully. It rightly pointed out that the mere fact that a question before a court 'is political in tone or context' cannot render the matter non-justiciable. ${ }^{33}$ Indeed, if that were the case, then few, if any, government decisions would be amenable to judicial review. Rather, the question is whether the issue amounts to a legal question, whatever political implications that question might have. Having established these basic propositions, the Court concluded that the issue before it was indeed a legal issue and that, as such, the issue could not be non-justiciable, legal questions being par excellence questions for the courts. $^{34}$

The Court reached this conclusion on the basis of its characterisation of the question that fell for determination. Crucially, the Court held that that question concerned not the exercise of the prorogation power, but the logically and legally prior issue of the scope of the power and whether its limits had been transgressed. Thus the Court rightly distinguished between questions about 'the lawfulness of the exercise of a prerogative power within its lawful limits' and (prior) questions about 'the lawful limits of the power and whether they have been exceeded'. ${ }^{35}$ The Court concluded that the issue in Miller II fell into the latter category because the constitutional principles in play served - in a way that I consider in detail below to limit the extent or scope of the power. Once the Court had characterised the issue in this way, concerns about justiciability necessarily fell away because, by definition, a question about whether the scope of a power has been exceeded is necessarily a question of law that manifestly lies within the field of matters with which courts can properly deal. This follows because the notion of justiciability is concerned only with limiting judicial involvement in the evaluation of the exercise of governmental powers whose use is capable of giving rise to questions that are unsuited, under the separation of powers, to analysis on legal grounds - and which are thus unsuited to determination by courts. The justiciability doctrine is, however, logically incapable of biting upon questions about whether a given power exists and, if so, what its legal boundaries are. The Court's view that the question was about the location and the crossing of such boundaries thus led ineluctably to the conclusion that the matter before it was justiciable.

\footnotetext{
${ }^{33}$ Miller II, supra n. 7, at [39].

${ }^{34}$ In adopting this approach, the Court largely aligned itself with the position that I argued it should adopt in a piece published online before argument in the case began before the Supreme Court: M. Elliott, 'Prorogation and Justiciability: Some Thoughts ahead of the Miller II Case in the Supreme Court', Public Law for Everyone, 12 September 2019, available at 〈publiclawforeveryone. com/2019/09/12/prorogation-and-justiciability-some-thoughts-ahead-of-the-cherry-miller-no2-case-in-the-supreme-court $\rangle$, visited 15 December 2020. The argument set out in that piece was relied upon extensively by counsel for Gina Miller during argument in the Supreme Court.

${ }^{35}$ Miller II, supra n. 7, at [36].
} 
The question arises, however, whether the Court's characterisation of the question as one concerning the extent, as distinct from the exercise, of the prorogation power can withstand analysis - not least in the light of suggestions that this approach amounted to an intellectual sleight of hand that rendered justiciable a matter that ought not to have been so regarded. It is to that question that I now turn.

\section{THE SCOPE OF THE POWER AND THE STANDARD OF REVIEW}

It is all very well saying that the matter before the Court in Miller II was justiciable because it merely required the Court to pronounce on whether the scope of the prerogative power had been exceeded - as distinct from making more fine-grained judgements about the manner in which an acknowledged power had been exercised. This distinction between questions about (on the one hand) the existence and scope of legal powers and (on the other hand) the manner of their exercise is not, of course, an entirely clean one. It is, however, a distinction to which considerable significance is attached, and upon which, as we have already seen, the Supreme Court placed substantial weight in this case. The question that now arises is whether that distinction, as conceived of by the Court in Miller II, is capable of bearing the weight that was placed upon it. In order to understand why there is at least a question mark in relation to this matter, it is necessary to examine the reasoning adopted by the Court - and to contrast it with a different form of reasoning that the Court might have adopted but did not. It is helpful to begin with the latter before turning to what the Court actually did.

It might have been expected that the Court would have approached matters by acknowledging that there is a prerogative to prorogue Parliament, such that there would have been no doubt about the existence of the power. The focus, on this approach, would then have shifted the question of whether the power had been exercised lawfully. There are, of course, a variety of grounds on which the exercise of governmental, including prerogative, powers can be challenged by way of judicial review, one of which is the principle of unreasonableness. However, as understood in English and UK public law, that principle generally permits judicial intervention only in very limited circumstances: at least traditionally, the applicable standard is one of manifest unreasonableness or absurdity. ${ }^{36}$ If this was the basis on which the Court had proceeded, then - even if matters pertaining to justiciability were left to one side - the likelihood of success on the part of the claimant would have been vanishingly small given the high threshold that would have needed to be cleared.

\footnotetext{
${ }^{36}$ See, classically, Associated Provincial Picture Houses Ltd v Wednesbury Corpn [1948] 1 KB 223; Council of Civil Service Unions v Minister for the Civil Service [1985] AC 374.
} 
In fact, however, the Court proceeded in a different fashion that had the dual effects of avoiding any justiciability-related obstacle and potentially enhancing the degree of scrutiny to which the decision was - or, for reasons that we will see, to which decisions of this nature can be - subject (relative to the level of scrutiny that would apply if the exercise of the power were to be evaluated by reference to the reasonableness standard). It did this by treating the existence of a 'reasonable justification ${ }^{37}$ not as a matter to be considered in evaluating the lawfulness of the exercise of the power but, rather, as a condition precedent to the exercise of the power. Another way of putting this is to say that, on the Court's view, it is only when there is a reasonable justification capable of supporting a decision to prorogue that there is, in the first place, any power to prorogue. In terms of legal characterisation, the question thus ceases to be one about the reasonableness of the exercise of an extant power (a question that would, from a claimant's perspective, be problematic in both justiciability and standard-of-review terms) and becomes a question about the legal existence and extent of the power.

Was this, then, a mere device to permit circumvention of the proper limits of the judicial role in cases such as this? That argument has certainly been advanced. For instance, John Finnis, in particularly strident terms, contends that the Court's reasoning amounts to 'a cover-giving device' and a 'card-shuffle', on the ground (he says) that it

'requires - or rather empowers! - the courts to examine the "manner of exercise" [of the power] while all the time protesting that they are not doing so, and are not making political judgments, and are not usurping the responsibility that the law and the constitution have assigned to others. Judicial review, thus conceived, covers the entire field, at the sovereign discretion of the judges. The Judgment's first claim, that the boundaries are legal, was a judicial fiat, and now the second claim, that the Judgment merely patrols boundaries, turns out to be a card-shuffle, a fudge. ${ }^{38}$

This critique does not, however, withstand analysis if we are prepared to accept as we surely must - that the decision in question, like any decision to prorogue Parliament, has the capacity to engage the principles of parliamentary sovereignty and executive accountability to Parliament. Once that fact is accepted as a starting-point, it becomes possible - and necessary - to locate the Miller II judgment within the wider canon of case law concerning judicial review of governmental decisions that potentially impinge upon fundamental constitutional rights and principles. Viewed thus, for all that Miller II was a momentous decision, its

${ }^{37}$ Miller II, supra n. 7, at [2].

${ }^{38}$ Finnis (2019), supra n. 15, at 14-15. 
recognition that the principle of legality (whether or not in name) applies to prerogative powers is a step that was wholly warranted in constitutional terms and firmly supported by existing constitutional principle.

The principle of legality has long been recognised as a principle of interpretation according to which legislation is to be read compatibly, where possible, with fundamental constitutional rights and principles. ${ }^{39}$ And while it is true that the Court in Miller II does not in terms apply the principle of legality, it is plain that in substance it applies that principle or at least a close relative of it to the prerogative. In doing so, the Court took a different path from that which had been adopted by the Divisional Court in $\mathrm{El} \mathrm{Gizouli,}{ }^{40}$ in which the principle of legality was considered to be limited to the statutory sphere. ${ }^{41}$ In contrast, in Miller II the Supreme Court makes it plain that the principle of legality - or at least the adjudicative technique for which that principle stands - is of sufficiently broad application to enable prerogative power to be limited by - just as statutory powers can be interpretively constrained by - fundamental constitutional principles.

This is surely correct. To reason, as the Divisional Court did in El Gizouli, that the principle of legality cannot operate so as to constrain prerogative power by reference to constitutional principles on the ground that the principle of legality is a merely interpretive principle is an entirely topsy-turvy way of looking at things. The better view is that the principle of legality is limited to operating as an interpretive principle (rather than as a rule of priority) in respect of statutory powers because nothing beyond this - given the sovereignty of Parliament - is constitutionally possible. In contrast, there is no good reason why the principle of legality should not - and are excellent reasons why it should - serve as a constraint, as distinct from a mere interpretive device, in respect of prerogative power. Principal among those reasons is the basic constitutional fact that the prerogative authority of the Crown is subject to and limited by the law, including fundamental legal-constitutional principles, in a way that the sovereign legislative authority of the Crown-in-Parliament is not and cannot be.

There is, therefore, a strong normative case for saying, as Alison Young does, that 'the principle of legality is not just a principle of statutory interpretation' and

\footnotetext{
${ }^{39} R \mathrm{v}$ Secretary of State for the Home Department, exp Pierson [1998] AC 539 at 587: 'Parliament does not legislate in a vacuum. Parliament legislates for a European liberal democracy founded on the principles and traditions of the common law. And the courts may approach legislation on this initial assumption. But this assumption only has prima facie force. It can be displaced by a clear and specific provision to the contrary'.

${ }^{40} R$ (El Gizouli) v Secretary of State for the Home Department [2019] EWHC 60 (Admin).

${ }^{41}$ When El Gizouli reached the Supreme Court ([2020] UKSC 10, [2020] 2 WLR 857), a majority of the Justices did not consider a relevant common law constitutional right to be in play, meaning that no decision needed to be taken by the majority on the applicability of the principle of legality to the prerogative.
} 
that it is 'also a constitutional principle establishing the limits of executive power'. ${ }^{42}$ Indeed, the question of whether prerogative power - as well as, through the medium of interpretation, statutory power - is subject to the principle of legality is one that goes to the basic normative and structural architecture of the UK constitution. The very fundamentality of the values that are safeguarded via the principle of legality demands nothing less than that they be prioritised with regard to prerogative power, and prioritised, so far the parameters of statutory construction and the principle of parliamentary sovereignty will permit, in respect of statutory power. As I have argued elsewhere, this insight is essential if we are to understand why it is permissible - and imperative - that prerogative power, as well as statutory power, is subject to judicial control so as to ensure that its extent and its exercise are aligned with fundamental constitutional principle. ${ }^{43}$

Once the conceptual decks are cleared in this way, the question becomes whether all of this is nevertheless a judicial ruse designed to ensure that the exercise of prerogative powers such as the prorogation power can be reviewed in a way that it ought not to be. In other words, is the Court, by treating the matter as one concerning the scope of power as distinct from its manner of exercise attempting to short-circuit the deferential approach to review that is normally applicable when questions about the reasonableness of a decision arise? Making the notion of 'reasonable justification' part and parcel of the threshold question concerning the scope of the power, as Supreme Court did in Miller II, might seem to support this narrative. Properly understood, however, the Miller II judgment is not, as some critics have suggested, constitutionally suspect: indeed, it is quite the reverse.

Once a fundamental right or value is in play, the normative appropriateness of a relatively close form of judicial scrutiny is self-evidently appropriate - and entirely consistent with well-established precedent. ${ }^{44}$ While a good deal of that precedent is concerned with circumstances in which fundamental rights

\footnotetext{
${ }^{42}$ A. Young, 'Prorogation, Politics and the Principle of Legality', UK Constitutional Law Blog, 13 September 2019, available at 〈ukconstitutionallaw.org/2019/09/13/alison-young-prorogationpolitics-and-the-principle-of-legality $\rangle$, visited 15 December 2020.

${ }^{43}$ For discussion, see M. Elliott, The Constitutional Foundations of Judicial Review (Hart Publishing 1999) ch. 5.

${ }^{44}$ This principle can be observed in a number of contexts. For instance, before judicial review on the ground of proportionality was more firmly established in English administrative law, it was held that the rationality principle would be applied in a particularly rigorous and searching manner in cases in which fundamental rights were at stake (see e.g., $R \mathrm{v}$ Ministry of Defence, exp Smith [1996] $Q B$ 517). In more recent case law, the relationship between the degree of judicial scrutiny that is warranted and the normative importance of the right or value that is in play is reflected in judgments delineating the scope of the proportionality doctrine and the intensity with which it is to be applied. For discussion, see H. Wilberg and M. Elliott (eds.), The Scope and Intensity of Substantive Review: Traversing Taggart's Rainbow (Hart Publishing 2015).
} 
(that are recognised at common law) are in play, the purview of close judicial scrutiny is certainly not confined to such circumstances. Of particular note in this regard is the courts' jurisprudence on ouster provisions. Viewed from one perspective, such provisions are an attack upon the right of access to the courts, and judicial preparedness to examine such provisions extremely closely, through the lens of statutory interpretation, amounts to a judicial defence of the right. ${ }^{45}$ However, viewed in broader perspective, the courts' approach to ouster clauses transcends the protection of rights, and the notably robust judicial approach often witnessed in this area can be accounted for by the fact that critical architectural features of the constitution, most obviously the separation of powers and the rule of law, are jeopardised by such statutory provisions. Admittedly, questions of reasonable justification are not normally in play in respect of ouster clauses, not least because such clauses are not themselves concerned with the exercise of administrative discretion (albeit that they seek to shield exercises of such discretion from judicial scrutiny). Nevertheless, the courts' case law on ouster clauses quite clearly illustrates that close scrutiny is certainly not limited to the rights context, as do cases that have established the availability of proportionality, or proportionalitystyle, review in relation to such matters as the protection of legitimate expectations ${ }^{46}$ and determinations regarding questions of fundamental status. ${ }^{47}$

It is misguided to suggest that shifting consideration of the question of reasonableness from the manner of exercise stage of review to the (logically prior) existence/scope of power stage amounts to an unwarranted attempt to elevate the standard of review. Rather, the inclusion of the possibility of reasonable justification at this stage of the analysis is imperative if an absolutist approach is to be avoided; looked at in this way, incorporating the question of reasonable justification at this stage of the analysis, far from being a device to ramp up the level of review, is in fact a necessary way of ensuring that review is not unwarrantedly strict and the court's approach inappropriately rigid. ${ }^{48}$ Such an approach is of a piece with judicial practice in the context of common law constitutional rights.

It is well-established that such rights can and do operate as constraints upon the scope of governmental powers by operation of the principle of legality - a

\footnotetext{
${ }^{45}$ See, e.g., Privacy International, supra n. 25.

${ }^{46}$ See, e.g., $R$ v North and East Devon Health Authority, ex p Coughlan [2001] QB 213.

${ }^{47}$ See, e.g., Pham v Secretary of State for the Home Department [2015] UKSC 19, [2015] 1 WLR 1591.

${ }^{48}$ This follows because once we acknowledge that fundamental constitutional principles properly serve as constraints upon the scope of executive authority, the omission of the possibility of justifying infractions on reasonable grounds would result in an absolute, utterly hard-edged limitation upon the power. The admission of a reasonable justification proviso ensures that constitutional principle can serve properly to condition the exercise of executive authority without serving as an unduly rigid straight-jacket.
} 
point that was explained with characteristic rigour by Laws J, as he then was, in the Witham case, in which it was held that legislation conferring a power in general words did not, absent specific and crystal-clear provision, authorise ministerial interference with the fundamental right of access to justice. ${ }^{49}$ In his judgment, Laws J made it perfectly clear that his reasoning was premised not on a finding that an extant power had been unreasonably or otherwise unlawfully exercised; rather, his decision turned on the basis of a 'vires argument', such that the unlawfulness of the impugned governmental act flowed from the absence, in the first place, of any authority to interfere with the relevant right. ${ }^{50}$

At the same time, however, this line of case law has never been absolutist. Thus in Leech - another access to justice case, and one on which Laws J went on to rely in Witham - legislation was interpreted as precluding ministerial interference with the right unless there was an objective justification for the interference. This demonstrated both that the principle of legality conferred qualified, rather than absolute, protection on common law constitutional rights and that the conceptual apparatus applied by the courts for determining the adequacy of the justification supplied a standard of review that went beyond the high-threshold reasonableness principle that applies to the review of the exercise of an extant power. There is no good legal or constitutional reason why this same approach should not apply when the power in question is a prerogative, rather than a statutory, power and when the at-risk constitutional norm is a fundamental constitutional principle as distinct from a common law constitutional right. In this way, the judgment in Miller II, by holding that the prerogative power of prorogation does not extend to suspending Parliament absent reasonable justification, is of a piece with existing case law on fundamental constitutional rights.

Finally, as regards the standard of review, it would be mistaken to assume that the Court's approach to the reasonable justification assessment, when enforcing scope-of-power limits derived from constitutional principle, will be uniformly high. Indeed, while this proposition was not significantly tested by the facts of Miller II the Court acknowledged this issue and signalled that it would be sensitive to it where relevant in the future. The reason why the proposition was not significantly tested in this case is thanks to the weakness of the Government's own case. This relieved the Court of any need to closely to evaluate the quality of the Government's reasons for the prorogation: instead, the Court found it 'impossible ... to conclude, on the evidence that has been put before us, that there was any reason - let alone a good reason - to advise Her Majesty to prorogue for five weeks'. ${ }^{51}$

\footnotetext{
${ }^{49} R$ v Lord Chancellor, ex $p$ Witham [1998] QB 575.

${ }^{50}$ Witham, supra n. 49 , at 586.

${ }^{51}$ Miller II, supra n. 7, at [61] (emphasis added).
} 
However, the Court also acknowledged that if relevant reasons had been offered, thus necessitating their qualitative evaluation by the Court, it would have recognised that 'the Government must be accorded a great deal of latitude in making decisions of this nature. ${ }^{52}$ This clearly implies that the standard of review of the quality of any reasons would have been relatively deferential bearing in mind the context, which in turn suggests that by applying the principle of legality the Court is not straightforwardly flicking a switch that swaps reasonableness for correctness, or low-intensity for high-intensity, review. Rather, the question remains whether there is reasonable justification - and what will be taken to constitute such justification will vary according to the context. Importantly, however, no occasion for such deference arose in Miller II because, to begin with, no reasons remotely capable of supporting the decision were offered by the Government. The proposition that the court will not and cannot defer to the executive in the absence of the executive having taken relevant steps, including by means of considering relevant issues and formulating relevant reasons, is uncontroversial, as the House of Lords acknowledged in Miss Behavin'. ${ }^{53}$

\section{BREAKING NEW GROUND?}

Having considered the key aspects of the judgment, we are in a position to step back and ask whether the Miller II judgment breaks new ground - and, relatedly, whether it warrants the criticism of judicial activism, even judicial overreach, that has been directed at it. Taken in isolation, none of the potentially innovative features of the case identified above is necessarily ground-breaking. From the doctrine of parliamentary sovereignty, the Court draws a sensible and warranted inference. The Court acknowledges that the notion of executive accountability to Parliament is not only (as has long been recognised) something that is institutionalised in convention, but is also a constitutional principle that is capable of informing analysis of the legality of executive action and shaping the parameters of governmental authority. Yet, in offering this insight, the Court does not affront the orthodox view that conventions are not legally enforceable. Meanwhile, the Court engages in judicial review in relation to a prerogative power that has never before been subject to review, but in doing so applies established principle, given that the Court is careful to frame its task as one of purely legal analysis. Moreover, the Court acknowledges that if relevant reasons had been advanced by the Government, its evaluation of their adequacy would have had to be informed by considerations of due deference, given the latitude that the government properly enjoys in this sphere. And in characterising the specific legal question that falls

\footnotetext{
${ }^{52}$ Miller II, supra n. 7, at [58].

${ }^{53}$ Belfast City Council v Miss Behavin' Ltd [2007] UKHL 19, [2007] 1 WLR 1420.
} 
to be answered, the Court invokes an existing principle - the principle of legality albeit in a novel way, by applying it to prerogative power.

It is possible, then, to present each part of the analysis in the case as at least relatively orthodox. However, the judgment's cumulative significance is greater than the sum of these parts, and it undoubtedly represents an important milestone in the narrative arc of modern public law in the UK. Taken in combination, the various factors that are at work in this judgment paint a picture of a Supreme Court judiciary that is prepared to serve as a guardian of constitutional principle in a way and to an extent that previous generations of apex court judges in the UK were not. What stands out about this case is the way in which fundamental constitutional principle is operationalised so as to produce significant and concrete limitations on governmental powers that have hitherto been considered to be no-go areas for the courts. In the principle of legality, the courts have long had at their disposal a powerful tool for confining the executive's legal capacity to affront fundamental constitutional principle. But in Miller II, the potential of that principle is writ large - thanks both to the Supreme Court's resistance to attempts artificially to limit or marginalise the relevant principles and to the Court's willingness to apply those principles not only to a prerogative power but to a power that was (incorrectly) considered to lie deep within political territory and thus to be wholly off limits to judicial review.

All of this suggests that, paradoxically, Miller II is at once both a legal landmark and an orthodox application of existing constitutional principle. The judgment affirms, articulates, clarifies, develops and applies fundamental principles governing the place of Parliament within the constitution and its relationship with the executive. In this sense, the judgment is either orthodox or is at least firmly rooted in orthodoxy. What renders the judgment a legal landmark is the willingness of the Court to take those principles to their logical conclusion in the face of a perfect storm of factors that, on the more superficial analysis favoured by the Divisional Court, appeared to close the door to judicial review. Thus the Supreme Court was prepared to draw inferences from, rather than relying exclusively on the formal core of, the principle of parliamentary sovereignty. It was willing to spell out the legal-constitutional implications of the political-constitutional principle of executive accountability to Parliament. It rejected the sloppy argument that because the issue had political implications it could not, at root, be a legal matter. It extended the principle of legality such that it now falls to be understood - as it always should have been - as a mechanism for giving concrete legal effect to fundamental constitutional principle, irrespective of whether the legal powers at stake are conferred by legislation or arise under the prerogative. And - crucially - the Court was prepared to take all of these steps simultaneously, 
with the result that what appeared, following the Divisional Court's judgment, to be an utterly hopeless case culminated in a powerfully reasoned and unanimous Supreme Court judgment.

This helps us to understand why the case is capable of being simultaneously rooted in orthodoxy and path-breaking. The Supreme Court was prepared to take a series of significant - but individually entirely legitimate - legal steps in circumstances that were politically extraordinary, resulting in the transformation of fundamental principle into hard and novel limits on executive authority. In doing so, the Court does something that is both trail-blazing and mundane. It is trailblazing because 'forbidden' executive territory has been shown to be anything but by a Court prepared to treat fundamental principle as something that is neither a mere rhetorical flourish nor something arid and technical to be understood in isolation from the broader constitutional landscape in which it sits. Yet the judgment is simultaneously mundane because, in the final analysis, it stands for the most modest of constitutional propositions: that the UK is a democracy founded on parliamentary sovereignty, executive accountability, and the subjugation of government to law; from those basic constitutional facts of life, it follows that the government is not afforded an unfettered power to deny the legislature the opportunity to perform its vital constitutional role; and that questions about the legal scope of government power are questions of law for courts of law. Once those self-evident propositions are accepted, it becomes clear that judicial intervention in this matter is a realisation of, not an affront to, the separation of powers. Indeed, for the Court to have declined to play its part, and to have refused to determine and enforce the legal limits upon the government's authority to suspend Parliament, would have been nothing other than a dereliction of its constitutional duty.

\section{BROADER CONSIDERATIONS}

It is worth concluding by reflecting on the legal, political and constitutional circumstances that prevail in the UK today, a year or so on from the Miller II judgment - and what the longer term implications might be of the admittedly muscular, if not ground-breaking, judicial approach that was on show in Miller II. The reaction to the judgment has certainly not been muted. Some of the academic criticism of it has already been noted, but criticism has extended well beyond the academy. It is, of course, far from unheard of for politicians on the receiving end of unwelcome court judgments to sound off about them. However, the political, including governmental, response to Miller II significantly breaches the usual parameters in this regard. 
Since the case was decided, the UK Government has initiated an Independent Review of Administrative Law. ${ }^{54}$ The Review's terms of reference contemplate the possibility of far-reaching changes to judicial review, including codifying (and thus potentially narrowing) the grounds on which Government action can be questioned by courts; attenuating the range of matters that courts can examine by redefining the concept of justiciability; limiting the remedial consequences of successful judicial review claims; reducing the Government's duty to disclose information in the course of judicial review proceedings; limiting who can initiate judicial review challenges in the first place; and altering the costs regime in a way that would make it financially more difficult for judicial review proceedings to be brought against the Government. Of course, none of these things might come to pass: the Review might not ultimately recommend any of these options that are, according to its terms of reference, open to it; Ministers might lack the political will or capital necessary to procure such changes; and Parliament might be unwilling to enact them. Nevertheless, the very fact that these possibilities are now on the table is in itself telling.

It is perfectly clear that Miller II forms part of the impetus for the Review, given the prominence accorded in the Review's terms of reference to concerns about justiciability and the possibility that courts may be unduly interfering with the Executive's 'right to govern'. It is also explicitly clear that Miller II has informed recently published proposals to repeal the Fixed-term Parliaments Act 2011, which displaced the prerogative power of dissolution, which could be used by Prime Ministers to call early general elections largely at a time of their choosing, and replaced it with a statutory framework requiring parliamentary approval of any proposal for an early election. The Draft Fixed-term Parliaments Act 2011 (Repeal) Bill ${ }^{55}$ would, if enacted, reinstate the prerogative power of dissolution while seeking, through a very broadly framed ouster clause, to exclude judicial review not only of the exercise of the power but also in relation to any questions concerning the scope of the power. The Explanatory Notes to the Draft Bill state in terms that the ouster clause is deliberately drafted so as to prevent a court from adopting in relation to the dissolution prerogative the sort of approach that the Supreme Court took in Miller II to the prorogation prerogative. ${ }^{56}$

\footnotetext{
${ }^{54}$ For details see 〈www.gov.uk/government/groups/independent-review-of-administrative-law〉, visited 15 December 2020.

${ }^{55}$ HM Government, Draft Fixed-term Parliaments Act 2011 (Repeal) Bill (CP 322, 2020), available at (www.gov.uk/government/publications/draft-fixed-term-parliaments-act-repeal-bill), visited 15 December 2020.

${ }^{56}$ Fixed-term Parliaments Act 2011 (Repeal) Bill: Explanatory Notes at [17], available at 〈www.gov.uk/government/publications/draft-fixed-term-parliaments-act-repeal-bill〉, visited 15 December 2020.
} 
In this way, it can be seen that Miller II forms the impetus for both a specific and targeted proposal to limit judicial review and a set of wider ranging possibilities, which may or may not follow from the Review, that could significantly curtail the courts' review powers more generally. The full implications of Miller II thus remain to be seen, given they may extend beyond the sphere of legal and constitutional doctrine if the case ultimately turns out to have lit the touchpaper for an attempt radically to overhaul - and limit - the courts' powers of judicial review. Should such an attempt be taken forward, it is impossible to predict with any certainty what the outcome would be. There is, however, a real prospect that the relationship between the judicial and political branches in the UK is set, over the coming years, to be characterised by peculiar degree of tension and potentially conflict.

The ultimate question that this set of circumstances raises is whether there are any legal and constitutional limits on the capacity of the UK Parliament to subvert the courts' judicial function. An unreconstructed understanding of the notion of parliamentary sovereignty would suggest that no such limits exist. But, as noted earlier in this article, such understandings of sovereignty have in recent years been eclipsed, including at the highest judicial level, by one that is more subtle, and which characterises parliamentary sovereignty as a constitutional principle that, while of critical importance, forms part of a network of fundamental principles, including the separation of powers and the rule of law. On this view, the very meaning of parliamentary sovereignty - and hence the degree of constitutional authority it ascribes to the legislative branch - is not an isolated matter, but is something that is informed by and must take account of the other fundamental principles with which it sits in relationship.

Miller II, of course, was not itself about the limits of Parliament's authority and its capacity to undermine the judicial function. Indeed, Miller II might be taken to sit in tension with the claims made immediately above, given that it was, in one sense, the Court's ringing endorsement of parliamentary sovereignty as an axiomatic constitutional principle that supplied the platform necessary for holding that executive action undermining that principle was unlawful. However, to read Miller II in this way would be to fail to situate it within the wider jurisprudential narrative of which it forms a critical element. Understood in these broader terms, Miller II is part of a line of Supreme Court case $\mathrm{law}^{57}$ that conceives of the UK constitution in terms whose normative richness transcends the sort the traditional, one-dimensional picture in which parliamentary sovereignty is treated as constitutional alpha and omega. From all of this, it follows that Miller II is very much a

\footnotetext{
${ }^{57}$ For prominent examples, see Privacy International, supra n. 25; $R$ (Evans) v Attorney General [2015] UKSC 21, [2015] AC 1787; R (Unison) v Lord Chancellor [2017] UKSC 51, [2017] 3 WLR 409.
} 
double-edged sword. It has plainly served as a trigger for a governmental attempt to clip the courts' wings (albeit that it remains to be seen what that attempt will ultimately amount to). At the same time, however, Miller II is shot through with an understanding of the British constitution that is built upon a set of interlocking fundamental principles of which the sovereignty of Parliament is but one - and which, in turn, means that the success of any attempt to undermine the courts' constitutional function should not be taken for granted, the hallowed notion of parliamentary sovereignty notwithstanding. 